\title{
THE EFFECT OF SMOKING ON DISEASE ACTIVITY IN RHEUMATOID ARTHRITIS - OUR EXPERIENCE
}

\author{
Ana Gudelj Gračanin ${ }^{1}$, Ivan Marković ${ }^{1}$, Majda Golob ${ }^{1}$, Marko Lucijanić \\ Ana Marija Valetić ${ }^{3}$ and Jadranka Morović-Vergles ${ }^{1}$
}

\begin{abstract}
${ }^{1}$ Division of Clinical Immunology, Allergology and Rheumatology, Department of Internal Medicine, Dubrava University Hospital, Zagreb, Croatia;

${ }^{2}$ Division of Hematology, Department of Internal Medicine, School of Medicine, University of Zagreb, Dubrava University Hospital, Zagreb, Croatia;

${ }^{3}$ Division of Clinical Immunology, Pulmonology and Rheumatology, Department of Internal Medicine, Sestre milosrdnice University Hospital Centre, Zagreb, Croatia
\end{abstract}

SUMMARY - The aim of this study was to investigate the association of smoking with disease activity, seropositivity, age and gender in patients with rheumatoid arthritis. We included 89 rheumatoid arthritis patients. All patients fulfilled the 2010 American College of Rheumatology/European League Against Rheumatism rheumatoid arthritis classification criteria. Activity of the disease was measured by Disease Activity Score 28-joint count C-reactive protein (DAS28CRP). The subjects were stratified into smoking and non-smoking groups and cross-sectionally analyzed. There were 24 (27\%) smokers and $65(73 \%)$ nonsmokers. The mean age of patients was $57.1 \pm 8.8$ years. The mean DAS28CRP was 5.81 in the smoking group and 5.57 in the non-smoking group, without statistically significant difference between the two groups $(\mathrm{p}=0.148)$. Similarly, smokers did not differ significantly from non-smokers according to age $(\mathrm{p}=0.443)$, gender $(\mathrm{p}=0.274)$, rheumatoid factor positivity $(\mathrm{p}=0.231)$, anti-citrullinated protein antibody positivity $(\mathrm{p}=0.754)$ or seropositivity $(\mathrm{p}=0.163)$. In this study, we found no association between smoking status and disease activity, seropositivity, age or gender in rheumatoid arthritis patients. Furthermore, disease activity was not related to age, gender or seropositivity. Additional studies on the effects of smoking on rheumatoid arthritis activity are needed.

Key words: Smoking; Rheumatoid arthritis; Rheumatoid factor

\section{Introduction}

Rheumatoid arthritis (RA) is a chronic systemic autoimmune disease characterized by synovitis and joint destruction. The etiology of RA is unknown. Genetic and environmental factors are considered to play an important role in the pathogenesis of the disease ${ }^{1}$. Smoking has been identified as a significant environmental risk factor for $\mathrm{RA}^{2}$.

Correspondence to: Ana Gudelj Gračanin, $M D, P h D$, Division of Clinical Immunology, Allergology and Rheumatology, Department of Internal Medicine, Dubrava University Hospital, Av. Gojka Šuška 6, HR-10000 Zagreb, Croatia

E-mail: agudelj@kbd.hr

Received October 4, 2018, accepted April 24, 2019
Tobacco consumption is a major public health problem in Croatia. Croatia conducted several antitobacco campaigns and programs in the past. However, results reveal that current strategies are ineffective in reducing the smoking prevalence, which has been estimated to $27.4 \%$ in our country ${ }^{3}$.

Tobacco consumption affects the immune system by producing an inflammatory response. It has been observed that smoking leads to the increased activity of B-cells and circulating polymorphonuclear cells, and to the increased levels of pro-inflammatory cytokines such as tumor necrosis factor alpha (TNF- $\alpha)$ and interleukin 6 (IL-6) ${ }^{4}$. Elevated levels of inflammatory markers have also been detected in non-smokers after short-term secondhand tobacco smoke exposure ${ }^{5}$. 
The exact pathogenetic effect of smoking on RA is not clear. Citrullination has been reported to be an important factor for the development of RA in the anticitrullinated protein antibodies (ACPA)-positive patients ${ }^{1}$. It has been shown that subjects with HLADRB1 who smoke have an increased risk of developing ACPA positive and severe $\mathrm{RA}^{6}$. The association of RA with HLA-DRB104 and its alleles 0401, 0404, 0405 or 0408 (known as shared epitope) is well established. Tobacco consumption is a significant risk factor for developing RA in individuals with shared epitope $^{7,8}$.

A meta-analysis of 16 studies estimated that the risk of developing RA was almost 2 times higher for male smokers and 1.3 times higher for female smokers compared to non-smokers. The association was more prominent for male rheumatoid factor $(\mathrm{RF})$ positive RA patients and for male heavy smokers, with summary odds ratios 3.91 and 2.31, respectively ${ }^{9}$. Another study also showed that smoking increased the risk of developing RA in men more than in women ${ }^{10}$. According to recent data, even light smoking is associated with inflammatory response and RA development ${ }^{5,11}$.

The effects of tobacco exposure on disease activity in RA patients are controversial. While some studies report increased severity of RA in smokers ${ }^{12-14}$, a significant number of studies, in contrast, found no correlation between smoking status and disease activity, as assessed by composite indices ${ }^{15-20}$. It is yet unclear whether tobacco effects might be reversible with smoking cessation. A recent study has reported that smoking cessation did not appear to significantly influence disease activity over time ${ }^{21}$. It is also unknown whether smoking effects on the course or severity of RA are limited to seropositive individuals.

The aim of this study was to evaluate the association between smoking and disease activity in RA. We also evaluated the association between smoking and seropositivity (presence of RF or ACPA, or both), age and gender, as well as the association between disease activity, age, gender and seropositivity in our patients.

\section{Patients and Methods}

A total of 89 patients with RA were cross-sectionally analyzed in Dubrava University Hospital during 2017. All patients fulfilled the 2010 American College of Rheumatology/European League Against Rheu- matism (ACR/EULAR) RA classification criteria. The patients were stratified according to the current smoking status into two groups: smoking group (current smokers) and non-smoking group (subjects who had never smoked). Disease activity was measured by the Disease Activity Score 28-joint count C-reactive protein (DAS28CRP). All patients were using glucocorticoids and/or disease-modifying antirheumatic drugs (DMARDs). RF and ACPA were analyzed by using current laboratory methods.

All procedures performed in this study were in accordance with the ethical standards of the institutional Research Committee on Human Experimentation and with the Declaration of Helsinki.

The normality of distribution of numerical variables was tested using the Kolmogorov-Smirnov test. Normally distributed numerical variables were presented as mean \pm standard deviation (SD), and nonnormally distributed variables were presented as median and interquartile range (IQR). Categorical variables were presented as proportions. The T-test, Mann Whitney U test, $\chi^{2}$-test, $\mathrm{McNemar}$ test and Spearman rank correlation were used where appropriate. The values of $\mathrm{p}<0.05$ were considered to be statistically significant. All statistical analyses were performed using MedCalc Statistical Software version 17.2 (MedCalc Software bvba, Ostend, Belgium).

\section{Results}

A total of 89 RA patients were included in the study. There were 19 (21.3\%) male and $70(78.7 \%)$ female patients, mean age $57.1 \pm 8.8$ years. The majority of subjects were seropositive (87.5\%), among which 79.3\% RF and 80.3\% ACPA positive. The mean DAS28CRP was 5.66. High disease activity (DAS28CRP $>5.1$ ) was recorded in 81 (91\%) subjects. Patient characteristics are shown in Table 1 , stratified according to smoking status.

There were 24 (27\%) smokers and 65 (73\%) nonsmokers. The proportion of men and women who smoked was $36.8 \%$ and $24.3 \%$, respectively. The mean DAS28CRP was 5.81 in the smoking group and 5.57 in the non-smoking group. No significant difference was observed in DAS28CRP between smokers and non-smokers ( $p=0.148)$ (Fig. 1). Similarly, smokers did not differ significantly from non-smokers according to age $(p=0.443)$, gender $(p=0.274), R F$ positivity 
Table 1. Patient characteristics stratified according to smoking status

\begin{tabular}{|l|l|l|l|l|}
\hline & Overall & Smokers & Non-smokers & p value \\
\hline Number of patients & 89 & $24(27 \%)$ & $65(73 \%)$ & - \\
\hline Age (years) & $57.1 \pm 8.8$ & $55.9 \pm 7.8$ & $57.5 \pm 9.1$ & 0.443 \\
\hline $\begin{array}{l}\text { Gender: } \\
\text { male } \\
\text { female }\end{array}$ & $\begin{array}{l}19 / 89(21.3 \%) \\
70 / 89(78.7 \%)\end{array}$ & $\begin{array}{l}7 / 24(29.2 \%) \\
17 / 24(70.8 \%)\end{array}$ & $\begin{array}{l}12 / 65(18.5 \%) \\
53 / 65(81.5 \%)\end{array}$ & 0.274 \\
\hline DAS28CRP & $5.7 \mathrm{IQR}(5.3-6.3)$ & $5.8 \mathrm{IQR}(5.4-6.5)$ & $5.6 \mathrm{IQR}(5.2-6.1)$ & 0.148 \\
\hline RF positive & $69 / 87(79.3 \%)$ & $16 / 23(69.6 \%)$ & $53 / 64(82.8 \%)$ & 0.231 \\
\hline ACPA positive & $61 / 76(80.3 \%)$ & $17 / 22(77.3 \%)$ & $44 / 54(81.5 \%)$ & 0.754 \\
\hline Seropositivity $(\mathrm{RF}$ or ACPA) & $77 / 88(87.5 \%)$ & $19 / 24(79.2 \%)$ & $58 / 64(90.6 \%)$ & 0.163 \\
\hline
\end{tabular}

The values of $\mathrm{p}<0.05$ were considered to be statistically significant; DAS28CRP = Disease Activity Score 28-joint count C-reactive protein; $\mathrm{RF}=$ rheumatoid factor; $\mathrm{ACPA}=$ anti-citrullinated protein antibodies

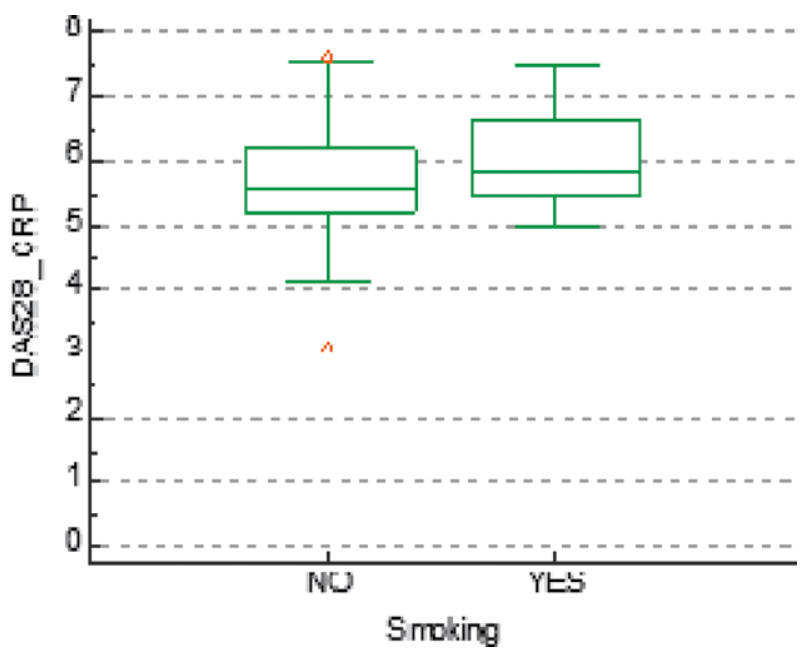

Fig. 1. No statistically significant association between smoking status and DAS28CRP in rheumatoid arthritis patients.

( $\mathrm{p}=0.231)$, ACPA positivity $(\mathrm{p}=0.754)$ or seropositivity in general ( $\mathrm{RF}$ or ACPA positivity) $(\mathrm{p}=0.163)$.

The RF and ACPA positive patients were older than seronegative patients $(\mathrm{p}=0.037$ and $\mathrm{p}=0.048$ for $\mathrm{RF}$ and ACPA positive patients, respectively). As expected, RF and ACPA positivity overlapped ( $\mathrm{p}<0.001)$. We also observed that female gender was more frequently associated with ACPA positivity, but this was not statistically significant $(\mathrm{p}=0.087)$.

Finally, DAS28CRP did not correlate with any of the evaluated parameters, i.e. age $(\mathrm{p}=0.184)$, gender $(\mathrm{p}=0.572)$, smoking status $(\mathrm{p}=0.148), \mathrm{RF}$ positivity $(\mathrm{p}=0.492)$, ACPA positivity $(\mathrm{p}=0.749)$ and seropositivity in general $(\mathrm{p}=0.394)$.

\section{Discussion}

While recent studies have implicated that smoking is one of the most important extrinsic risk factors for RA development, the role of tobacco exposure in RA activity is still controversial. Some studies report increased severity of RA in smokers ${ }^{12-14}$. In a recent study, current smoking status in ACPA positive patients was associated with elevated levels of proinflammatory cytokines and increased RA activity 22 . On the other hand, a significant number of studies found no correlation between smoking status and disease activity assessed by composite indices ${ }^{15-20}$.

Smoking is known to trigger HLA-DR-restricted immune reactions to autoantigens modified by citrullination ${ }^{8}$. Cigarette smokers have a higher risk of developing ACPA, and smoking has been shown to affect the severity of RA in genetically susceptible patients with the HLA-DRB1 shared epitope ${ }^{7}$. In this study, however, we found no significant difference in ACPA and RF seropositivity between smokers and non-smokers.

So far, to our knowledge, two longitudinal observational studies investigated the effect of smoking cessation on disease activity in RA. Neither study showed improvement in RA severity after stopping smoking $^{19,23}$. Moreover, in the Swedish cohort of patients with early RA, smoking cessation was negatively associated with EULAR good outcome at 8 years ${ }^{19}$. Lu et al. revealed that current smoking was not associated with DAS28CRP, but was associated with more functional disability, as measured by the modified Health Assessment Questionnaire (HAQ ${ }^{17}$. Furthermore, the 
effect of tobacco consumption on radiographic progression in RA is not clear. Ruiz-Esquide et al. followed a cohort of 156 early RA patients for 2 years and concluded that smoking was independently associated with radiographic progression ${ }^{14}$. Conversely, Vesperini et al. showed among 641 subjects with RA that 1-year radiographic progression was lower in current smokers than nonsmokers. The authors also found significantly lower baseline CRP levels and erythrocyte sedimentation rate (ESR) in current smokers than nonsmokers and ex-smokers, despite the similar disease activity and functional capacity across the groups ${ }^{16}$. Nevertheless, tobacco use seems to be a predictor of the development of severe extra-articular manifestations in $\mathrm{RA}^{21}$.

The TNF- $\alpha$ inhibitors represent a major advance in RA treatment and have considerably improved the disease outcomes ${ }^{23}$. It has been demonstrated that patients with RA who smoked were less likely to respond to TNF- $\alpha$ inhibitor therapy ${ }^{24-27}$. Furthermore, treatment failure has been associated with the number of pack years ${ }^{24}$. Tobacco use has also been shown to negatively affect treatment with methotrexate ${ }^{26}$. In the study by Ramiro et al., smoking was a predictor of discontinuation of the first biologic drug ${ }^{27}$.

Patients with RA have an increased risk of cardiovascular morbidity and mortality compared to the general population, resulting from accelerated atherogenesis that has been linked to the extent of systemic inflammation ${ }^{28}$. RA has been recognized as an independent cardiovascular risk factor, the effect of which is comparable to that of type 2 diabetes mellitus ${ }^{29}$. It is therefore important in clinical practice to appropriately address and manage other preventable risk factors for atherosclerosis in RA patients, and to implement the treat-to-target strategy to minimize systemic inflammation.

In this study, we found no significant difference in RA disease activity according to DAS28CRP between smokers and non-smokers (Fig. 1). However, there was a tendency to a more severe disease in cigarette smokers. There was no association between tobacco consumption and seropositivity (presence of RF or ACPA, or both), age or gender in our patients either. There were more cigarette smokers among seronegative RA patients, but it was not statistically significant.

We found an association between seropositivity and age in RA patients, i.e. the patients with seroposi- tive RA were older. There was a tendency for female patients to have ACPA positive disease, although it was not statistically significant.

The main limitation of our study was that the majority of included subjects had a high disease activity, so the results may not be generalized to the entire population of RA patients. Our results need to be further verified in larger studies, preferably with adjustment for genetic analysis and cytokine response.

\section{Conclusion}

In our study, the role of tobacco exposure in RA activity did not show significant difference between the two groups, and the results were consistent with other recent studies. The study included a small group of patients from Dubrava University Hospital, therefore additional investigations on the topic should be conducted in a larger group of patients.

\section{References}

1. Scott DL, Wolfe F, Huizinga TW. Rheumatoid arthritis. Lancet. 2010;376:1094-108. doi: 10.1016/S0140-6736(10)60826-4.

2. Chang K, Yang SM, Kim SH, Han KH, Park SJ, Shin JI. Smoking and rheumatoid arthritis. Int J Mol Sci. 2014; 15:22279-95. doi: 10.3390/ijms151222279.

3. Padjen I, Dabić M, Glivetć T, Biloglav Z, Biočina-Lukenda D, Lukenda J. The analysis of tobacco consumption in Croatia are we successfully facing the epidemic? Cent Eur J Public Health. 2012;20(1):5-10.

4. Sopori ML, Kozak W. Immunomodulatory effects of cigarette smoke.J Neuroimmunol. 1998;83:148-56. doi: 10.1016/s01655728(97)00231-2.

5. Zhang J, Fang SC, Mittleman MA, Christiani DC, Cavallari JM. Seconhand tobacco smoke exposure and heart rate variability and inflammation among non-smoking construction workers: a repeated measures study. Environ Health. 2013; 12:83. doi: 10.1186/1476-069x-12-83.

6. Padyukov L, Silva C, Stolt P, Alfredsson L, Klareskog L. A gene-environment interaction between smoking and shared epitope genes in HLA-DR provides a high risk of seropositive rheumatoid arthritis. Arthritis Rheum. 2004;50:3085-92. doi: 10.1002/art.20553.

7. Mattey DL, Hutchinson D. Smoking and HLA-DR shared epitope alleles in rheumatoid arthritis: comment on the article by Padyukov et al. Arthritis Rheum. 2005;52:3675-8. doi: 10.1002/art.21504.

8. Kallberg H, Padyukov L, Plenge RM, Ronnelid J, Gregersen $\mathrm{PK}$, van der Helm-van Mil AH, et al. Gene-gene and gene- 
environment interactions involving HLA-DRB1, PTPN22 and smoking in two subset of rheumatoid arthritis. Am J Hum Genet. 2007;80:867-77. doi: 10.1086/516736.

9. Sugiyama D, Nishimura K, Tamaki K, Tsuji G, Nakazawa T, Morinobu A, et al. Impact of smoking as a risk factor for developing rheumatoid arthritis: a meta-analysis of observational studies. Ann Rheum Dis. 2010;69:70-81. doi: 10.1136/ard. 2008.096487.

10. Heliovaara M, Aho K, Aromaa A, Knekt P, Reunanen A. Smoking and risk of rheumatoid arthritis. J Rheumatol. 1993; 20:1830-5.

11. Di Giuseppe D, Discacciati A, Orsini N, Wolk A. Cigerette smoking and risk of rheumatoid arthritis: a dose-response meta-analysis. Arthritis Res Ther. 2014;16:61.

12. Manfredsdottir VF,Vikingsdottir T, Jonsson T, Geirsson AJ, Kjartansson O, Heimisdottir M, et al. The effects of tobacco smoking and rheumatoid factor seropositivity on disease activity and joint damage in early rheumatoid arthritis. Rheumatology (Oxford). 2006;45:734-40. doi: 10.1093/rheumatology/ kei240.

13. Papadopoulos NG, Alamanos Y, Voulgari PV, Epagelis EK, Tsifetaki N, Drosos AA. Does cigarette smoking influence disease expression, activity and severity in early rheumatoid arthritis patients? Clin Exp Rheumatol. 2005;23:861-6.

14. Ruiz-Esquide V, Gómez-Puerta JA, Cañete JD, Graell E, Vazquez I, Ercilla MG, et al. Effects of smoking on disease activity and radiographic progression in early rheumatoid arthritis.J Rheumatol. 2011;38:2536-9. doi: 10.3899/jrheum.110410.

15. Haye Salinas MJ, Retamozo S, Alvarez AC, Maldonado Ficco H, Dal Pra F, Citera G, et al. Effects of cigarette smoking on early arthritis: a cross-sectional study - data from the Argentine Consortium for Early Arthritis (CONAART). Rheumatol Int. 2015;35:855-9. doi: 10.1007/s00296-014-3188-7.

16. Vesperini V, Lukas C, Fautrel B, Le Loet X, Rincheval N, Combe B. Association of tobacco exposure and reduction of radiographic progression in early rheumatoid arthritis: results from a French multicenter cohort. Arthritis Care Res (Hoboken). 2013;65:1899-906. doi: 10.1002/acr.22057.

17. Lu B, Rho YH, Cui J, Iannaccone CK, Frits ML, Karlson EW, et al. Associations of smoking and alcohol consumption with disease activity and functional status in rheumatoid arthritis. J Rheumatol. 2014;41:24-30. doi: 10.3899/jrheum.130074.

18. Söderlin MK, Petersson IF, Bergman S, Svensson B; BARFOT study group. Smoking at onset of rheumatoid arthritis (RA) and its effect on disease activity and functional status: experiences from BARFOT, a long-term observational study on early RA. Scand J Rheumatol. 2011;40:249-55. doi: 10.3109/ 03009742.2010.541495.

19. Andersson ML, Bergman S, Söderlin MK.The Effect of stopping smoking on disease activity in rheumatoid arthritis (RA).
Data from BARFOT, a multicenter study of early RA. Open Rheumatol J. 2012;6:303-9. doi: 10.2174/18743129012060 10303.

20. Nyhäll-Wåhlin BM, Petersson IF, Nilsson JA, Jacobsson LT, Turesson C; BARFOT study group. High disease activity, disability burden and smoking predict severe extra-articular manifestations in early rheumatoid arthritis. Rheumatology $\left(\mathrm{Ox}^{-}\right.$ ford). 2009;48:416-20.

21. Fisher MC, Hochberg MC, El-Taha M, Kremer JM, Peng C, Greenberg JD. Smoking, smoking cessation, and disease activity in a large cohort of patients with rheumatoid arthritis. CORRONA Investigators. J Rheumatol. 2012;39:904-9. doi: 10.3899/jrheum.110852.

22. Sokolove J, Wagner CA, Lahey LJ, Sayles H, Duryee MJ, Reimold AM, et al. Increased inflammation and disease activity among current cigarette smokers with rheumatoid arthritis: a cross-sectional analysis of US veterans. Rheumatology $(\mathrm{Ox}-$ ford). 2016;55:1969-77. doi: 10.1093/rheumatology/kew285.

23. Ma X, Xu S. TNF inhibitor therapy for rheumatoid arthritis. Biomed Rep. 2013;1:177-84. doi: 10.3892/br.2012.42.

24. Mattey DL, Brownfield A, Dawes PT. Relationship between pack-year history of smoking and response to tumor necrosis factor antagonists in patients with rheumatoid arthritis. J Rheumatol. 2009;36:1180-7. doi: 10.3899/jrheum.081096.

25. Saevarsdottir S, Wedrén S, Seddighzadeh M, Bengtsson C, Wesley A, Lindblad S, et al. Patients with early rheumatoid arthritis who smoke are less likely to respond to treatment with methotrexate and tumor necrosis factor inhibitors: observations from the Epidemiological Investigation of Rheumatoid Arthritis and the Swedish Rheumatology Register cohorts. Arthritis Rheum. 2011;63:26-36. doi: 10.1002/art.27758.

26. Canhão H, Rodrigues AM, Mourão AF, Martins F, Santos MJ, Canas-Silva J, et al. Comparative effectiveness and predictors of response to tumour necrosis factor inhibitor therapies in rheumatoid arthritis. Rheumatology (Oxford). 2012;51:2020-6.

27. Ramiro S, Landewé R, van der Heijde D, Harrison D, Collier $\mathrm{D}$, Michaud K. Discontinuation rates of biologics in patients with rheumatoid arthritis: are TNF inhibitors different from non-TNF inhibitors? RMD Open. 2015;18:1. doi: 10.1136/ rmdopen-2015-000155.

28. Mohan A, Sada S, Kumar BS, Sarma KV, Devi BV, Rao PV, et al. Subclinical atherosclerosis in patients with rheumatoid arthritis by utilizing carotid intima-media thickness as a surrogate marker. Indian J Med Res. 2014;140:379-86.

29. Van Hlam VP, Peters MJ, Voskuyl AE, Boers M, Lems WF, Visser M, et al. Rheumatoid arthritis versus diabetes as a risk factor for cardiovascular disease: a coss-sectional study, the CARRE Investigation. Ann Rheum Dis. 2009;68:1395-400. doi: 10.1136/ard.2008.094151. 


\title{
Sažetak \\ UTJECAJ PUŠENJA NA AKTIVNOST BOLESTI
U BOLESNIKA S REUMATOIDNIM ARTRITISOM - NAŠA ISKUSTVA
}

\author{
A. Gudelj Gračanin, I. Markovic, M. Golob, M. Lucijanic, A. M. Valetić i J. Morović-Vergles
}

Cilj ovoga istraživanja bio je ispitati povezanost pušenja s aktivnošću bolesti, pozitivnim biokemijskim biljezima, dobi i spolom kod bolesnika s reumatoidnim artritisom. $U$ istraživanju je sudjelovalo 89 ispitanika koji su bolovali od reumatoidnog artritisa. Svi ispitanici su ispunjavali klasifikacijske kriterije za postavljanje dijagnoze reumatoidnog artritisa Američkog reumatološkog društva i Europske reumatološke udruge (engl. European League Against Rheumatism, EULAR). Aktivnost bolesti mjerena je prema indeksu aktivnosti bolesti (engl. Disease Activity Score, DAS) koja se procjenjuje na 28 zglobova. Ispitanici su podijeljeni u dvije skupine (pušači i nepušači) koje su presječno analizirane. U ispitivanju je sudjelovalo 24 (27\%)

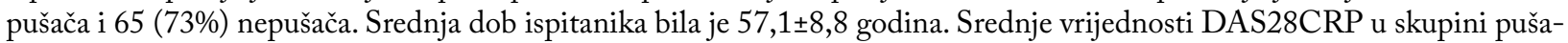
ča iznosile su 5,81, a u skupini nepušača 5,57, odnosno nije bilo statistički značajne razlike između dviju skupina $(\mathrm{p}=0,148)$. Također, skupina u kojoj su bili pušači nije se značajno razlikovala u parametrima dobi $(\mathrm{p}=0,443)$, spola $(\mathrm{p}=0,274)$, pozitivnog reumatoidnog faktora $(\mathrm{p}=0,231)$, pozitivnih anti-citrulinskih protutijela $(\mathrm{p}=0,754)$ ili seropozitivnosti $(\mathrm{p}=0,163)$ od skupine nepušača. U ovom istraživanju nismo pronašli povezanost između pušenja i aktivnosti bolesti, seropozitivnosti, dobi i spola kod bolesnika s reumatoidnim artritisom. Nadalje, aktivnost bolesti nije bila povezana s dobi, spolom i seropozitivnošću. Potrebna su daljnja istraživanja utjecaja pušenja na aktivnost reumatoidnog artritisa.

Ključne riječi: Pušenje; Reumatoidni artritis; Reumatoidni faktor 